\title{
EFFECT OF IRRIGATION AND ANNUAL SEASONS ON THE CHEMICAL COMPOSITION AND DIGESTIBILITY OF GRASSES UNDER GRAZING
}

\author{
Carlos Augusto Brasileiro de Alencar ${ }^{1}$, Fernando França da $\mathrm{Cunha}^{2}$, Rubens Alves de Oliveira ${ }^{3}$, \\ Antônio Carlos Cóser ${ }^{4}$, Carlos Eugênio Martins ${ }^{5}$
}

\begin{abstract}
The aim of the study was to evaluate the chemical composition and in vitro dry matter digestibility (IVDMD) of six grasses subjected to different irrigation depths and seasons. The experiment was conducted in a completely randomized arrangement with two replications in a split-split plot design. The treatments included plots with six grasses (Xaraés, Mombaça, Tanzania, Pioneiro, Marandu and Estrela), six irrigation depths for the split-plots (0\%, 18\%, 45\%, 77\%, $100 \%$ and $120 \%$ of the reference value provided by the tensiometer), and two seasons as the split-split plots (autumn/ winter and spring/summer). A line source sprinkler system was used for application of the irrigation depths. Crude protein (CP), neutral detergent fiber (NDF) and IVDMD were evaluated and obtained in accordance with literature. The factors studied affect the CP. However in the autumn/winter season the grasses presented differences in the NDF content, where Estrela presented the largest and Pioneiro the smallest NDF contents. The season and irrigation depths did not affect the NDF. Estrela grass presented the smallest IDVMD and the autumn/winter season resulted in greater digestibility for the grasses Xaraés, Mombaça and Tanzania only. The irrigation depths had an effect on some combinations of grasses and seasons.
\end{abstract}

Keywords: crude protein, line source sprinkler system, neutral detergent fiber

\section{RESUMO}

\section{IRRIGAÇÃO E ESTAÇÕES ANUAIS NA COMPOSIÇÃO BROMATOLÓGICA E DIGESTIBILIDADE DE CAPINS CULTIVADOS SOB PASTEJO}

Objetivou-se com este estudo avaliar a composição bromatológica e a digestibilidade in vitro da matéria seca (DIVMS) em seis capins manejados por pastejo sob efeito de diferentes lâminas de irrigação e estações do ano. O experimento foi conduzido em esquema de parcelas subsubdivididas, tendo nas parcelas seis gramíneas (Xaraés, Mombaça, Tanzânia, Pioneiro, Marandu e Estrela), nas subparcelas seis lâminas de irrigação (0, 18, 45, 77, 100 e 120\% da referência dada pelo tensiômetro) e nas subsubparcelas as estações (outono/inverno e primavera/verão) no delineamento inteiramente casualizado, com duas repetições. Para diferenciar a aplicação das lâminas de irrigação, utilizou-se o sistema por aspersão em linha. Foram avaliados os teores de proteína bruta (PB), fibra em detergente neutro (FDN) e a DIVMS e suas obtenções foram de acordo com a literatura. Os fatores estudados afetaram o teor de PB. Apenas na estação outono/inverno os capins apresentaram diferença no teor de FDN, sendo a Estrela a maior e Pioneiro os menores teores encontrados. As estações do ano e lâminas de irrigação não afetaram a FDN. O capim-estrela apresentou menor DIVMS e a estação outono/inverno proporcionou maior digestibilidade apenas para os capins Xaraés, Mombaça e Tanzânia. As lâminas de irrigação conferiram efeito em algumas combinações de capim e estação anual.

Palavras-chave: aspersão em linha, fibra em detergente neutro, proteína bruta

\section{Recebido para publicação em 12/06/2012. Aprovado em 16/04/2014.}

1 - Engenheiro Agrícola, Doutor em Eng. Agrícola, Diretor Geral, IBIO/Governador Valadares, MG. E-mail: brasileiro@ibio.org.br

2 - Agrônomo, Doutor em Eng. Agrícola, Professor Adjunto, UFMS/Chapadão do Sul, MS. E-mail: fernando.cunha@ufms.br

3 - Engenheiro Agrícola, Doutor em Eng. Agrícola, Professor Adjunto, UFV/Viçosa-MG, Brasil. E-mail: rubens@ufv.br

4 - Engenheiro Agrônomo, Doutor em Agronomia, Pesquisador, Embrapa/Juiz de Fora-MG, Brasil. Email: acoser@cnpgl.embrapa.br

5 - Agrônomo, Doutor em Agronomia, Pesquisador, Embrapa/Juiz de Fora-MG, Brasil. Email: caeuma@cnpgl.embrapa.br 


\section{INTRODUCTION}

Animal performance is directly linked to the consumption and quality of dry forage matter because it determines the amount of nutrients that must be ingested by animals to meet their demands for maintenance and production (LIMA et al., 2001; CUNHA et al., 2010). Forage plant utilization efficiency by animals is dependent on several factors such as the quality and quantity of forage available in the pasture and genetic potential of the animal. Therefore, when forage availability and potential of the animal are not limiting factors, forage quality is defined by production per animal and is directly linked to the intake and availability of nutrients contained in it (REIS et al., 1992).

In irrigated areas the nutritional value of forage throughout the year is different compared to nonirrigated pastures. During dry spells that mainly occur in the winter there is a decrease in nutritive value of the forage. Supplementation of water by irrigation can alter the chemical composition and nutritional quality of these plants. The concept of nutritional value refers to the chemical composition of the forage and digestibility (GERDES et al., 2000).

Cóser et al. (2008), when studying the effect of different water depths on the nutritive value of elephant grass noted that the crude protein content and in vitro digestibility of dry matter were not affected by irrigation depth. Only during the rainy season was the content of neutral detergent positively influenced by the irrigation depth. Marcelino et al. (2003) studied the effect of water availability and nitrogen fertilization in areas cultivated with Tifton 85 (Cynodon dactylon), and observed that the efficiency of nitrogen was obtained in the condition of highest soil water content.

The aim of this study was to evaluate the crude protein, neutral detergent fiber and in vitro digestibility of dry matter for six grasses managed in pastures located in eastern Minas Gerais under different irrigation depths and during different seasons.

\section{MATERIAL AND METHODS}

This study was carried out at the University Vale do Rio Doce located in Governador Valadares city, Brazil, with the geographic coordinates of $18^{\circ} 47^{\prime}$
30 " south latitude and $41^{\circ} 59^{\prime} 04$ " west longitude and elevation of $223 \mathrm{~m}$.

The average rainfall and potential evapotranspiration reference during the two years of the experiment were $1,064 \mathrm{~mm}$ and $1,277 \mathrm{~mm}$, respectively. In the experimental area the soil was classified as eutrophic Cambisol, medium texture, with the following chemical composition at 0 to $30 \mathrm{~cm}: \mathrm{pH}\left(\mathrm{H}_{2} \mathrm{O}\right)=6.5, \mathrm{MO}=1.6 \mathrm{~g} \mathrm{dm}^{-3}, \mathrm{P}=6.0$ $\mathrm{mg} \mathrm{dm}{ }^{-3}, \mathrm{~K}^{+}=60 \mathrm{mg} \mathrm{dm}{ }^{-3}, \mathrm{Ca}^{2+}=3.8 \mathrm{cmol}_{\mathrm{c}} \mathrm{dm}^{-3}$; $\mathrm{Mg}^{2+}=1.0 \mathrm{cmol}_{\mathrm{c}} \mathrm{dm}^{-3} ; \mathrm{Al}^{3+}=0.1 \mathrm{cmol}_{\mathrm{c}} \mathrm{dm}^{-3} ; \mathrm{H}+$ $\mathrm{Al}=4.0 \mathrm{cmol}_{\mathrm{c}} \mathrm{dm}^{-3}$ and $\mathrm{V}=55 \%$. Fertilization at planting consisted of $100 \mathrm{~kg} \mathrm{ha}^{-1}$ of $\mathrm{P}_{2} \mathrm{O}_{5}$, applied as superphosphate which provided all the phosphorus in the bottom of the row. The overall fertilization consisted of $50 \mathrm{~kg} \mathrm{ha}^{-1} \mathrm{yr}^{-1}$ of $\mathrm{P}_{2} \mathrm{O}_{5}, 150 \mathrm{~kg} \mathrm{ha}^{-1} \mathrm{yr}^{-1}$ of $\mathrm{K}_{2} \mathrm{O}$ and $300 \mathrm{~kg} \mathrm{ha}^{-1} \mathrm{yr}^{-1}$ of $\mathrm{N}$, where the sources were superphosphate, potash and urea, respectively, applied by broadcasting during any time of the year. Potassium chloride and urea were applied by broadcasting at six different times during the year.

The particle size distribution and the results of the physic soil water were as follows: clay $=30 \%$, silt $=25 \%$, sand $=45 \%$; field capacity $=0.30 \mathrm{~g}$ $\mathrm{g}^{-1}$; wilting point $=0.17 \mathrm{~g} \mathrm{~g}^{-1}$ and bulk density $=$ $1.38 \mathrm{~g} \mathrm{~cm}^{-3}$. Soil bulk density was determined by the volumetric ring method and levels of soil water content at field capacity and wilting point were determined for the tensions of 10 and $1500 \mathrm{kPa}$, respectively. The amounts of water retention in the soil were determined using the Richards chamber's method (RICHARDS, 1949).

The experiment was conducted in a split-split plot scheme, in which the plots were the grasses (Brachiaria brizantha cv. Xaraés, Panicum maximum cv. Mombaça, Panicum maximum cv. Tanzânia, Pennisetum purpureum cv. Pioneiro, Brachiaria brizantha cv. Marandu and Cynodon nlemfuensis L. cv. Estrela), the subplots the irrigation depths $(0,101,252,431,560$ and 672 $\mathrm{mm} \mathrm{yr}^{-1}$, corresponding to $0,18,45,77,100$ and $120 \%$ of the reference value obtained using a tensiometer, respectively) and the sub-subplots consisted of the seasons (autumn/winter season from April to September and the spring/summer season from October to March) in a completely randomized design with two replications.

The experimental plots measured $6 \mathrm{~m}$ wide

\section{REVENG}


by $18 \mathrm{~m}$ long. These plots were subdivided into six equal parts resulting in subplots of $6 \times 3 \mathrm{~m}$ $\left(18 \mathrm{~m}^{2}\right)$. The water depths were derived from different distributions of water in the direction perpendicular to the pipe with sprinklers. For this purpose the irrigation system with sprinklers on the distribution line (Line Source Sprinkler System) was used according to Hanks et al. (1976). The irrigation depth reference (100\%) was determined by monitoring the soil water potential with a digital tensiometer installed at depths of 15 and $45 \mathrm{~cm}$. Irrigation was performed when the tensiometer installed at $15 \mathrm{~cm}$ recorded values of matric potential of approximately $-60 \mathrm{kPa}$. Irrigation applied was measured using gauges installed in each experimental subplot and calculated by means of Equation 1.

$$
\mathrm{L}=\frac{(\mathrm{CC}-\theta)}{10} \mathrm{DZ} \frac{1}{\mathrm{Ea}}
$$

Where,

$\mathrm{L}=$ total depth required (mm);

$\mathrm{CC}=$ field capacity $(\%$ dry basis $)$;

$\theta=$ soil water content at matric potential of $-60 \mathrm{kPa}$

(\% dry basis);

$\mathrm{D}=$ soil bulk density $\left(\mathrm{g} \mathrm{cm}^{-3}\right)$;

$\mathrm{Z}=$ effective root depth $(\mathrm{cm})$; and

$\mathrm{Ea}=$ water application efficiency (decimal).

Simultaneously with the monitoring of soil water content via the tensiometer, daily weather data was collected from an automatic weather station installed in the experimental area.

The experiment was conducted under pasture management. At 45 days after uniform cutting the first grazing of the subplots was performed so that the residue remaining after grazing presented around $15 \%$ of remaining green leaves, as indicated by Aroeira et al. (1999). The same procedure was adopted in other collections with subsequent grazing, however with intervals of 30 days. The animals were used only as "cutting tool" after sampling of each grass, so that the forage was consumed.

The systematic collection of samples was performed manually in an area bounded by a metal rectangular unit with size of approximately $1.0 \mathrm{x}$ $0.5 \mathrm{~m}$ (area of $0.5 \mathrm{~m}^{2}$ ), before entry of the animals.
The potentially consumable green mass was harvested and packaged in bags, properly identified and immediately weighed. Then the material was placed to dry in an oven with air circulation at 60 ${ }^{\circ} \mathrm{C}$ for a period of 72 hours.

Samples collected in their respective plots were combined for the evaluation of chemical composition and in vitro digestibility of dry matter (IVDMD). They were then milled using a Willey mill with one millimeter mesh sieve and stored in properly identified containers.

The crude protein (CP), neutral detergent fiber (NDF) and IVDMD were determined by methods described by Silva and Queiroz (2002). These determinations were performed at the National Research Center of Dairy Cattle of the Brazilian Agricultural Research Corporation.

Data was submitted to analysis of variance and regression. Comparison of means was performed using the Tukey test at 5\% probability. For the quantitative factors, the models were selected based on the significance of the regression coefficients, using the test at $10 \%$ probability, the coefficient of determination $\left(\mathrm{R}^{2}\right)$ and the biological phenomenon. For carrying out the statistical analyses the software SAEG 9.0 was utilized.

\section{RESULTS AND DISCUSSION}

Figure 1 presents the average monthly values for the meteorological variables obtained during the study period. The average values of solar radiation presented large fluctuations during the entire experimental period and ranged from 738 to $1103 \mathrm{~W} \mathrm{~m}^{-2}$ during the dry (between April and September) and rainy seasons (October-March), respectively. This behavior influenced the values of temperature and consequently the reference evapotranspiration (ETo). Average temperatures during the experiment ranged from 18.7 to 25.6 ${ }^{\circ} \mathrm{C}$, reaching a maximum between the months of October and March and minimum between the months of April and September. The mean monthly values of ETo during the study ranged from 1.92 to $4.98 \mathrm{~mm} \mathrm{day}^{-1}$, where the lowest was in May 2004 and the maximum in October 2003. Average relative humidity ranged from 69 to $97 \%$. Behavior of the relative humidity was the opposite of solar radiation and temperature, where maximum values were observed during the months of December and May and minimum values between June and November. 


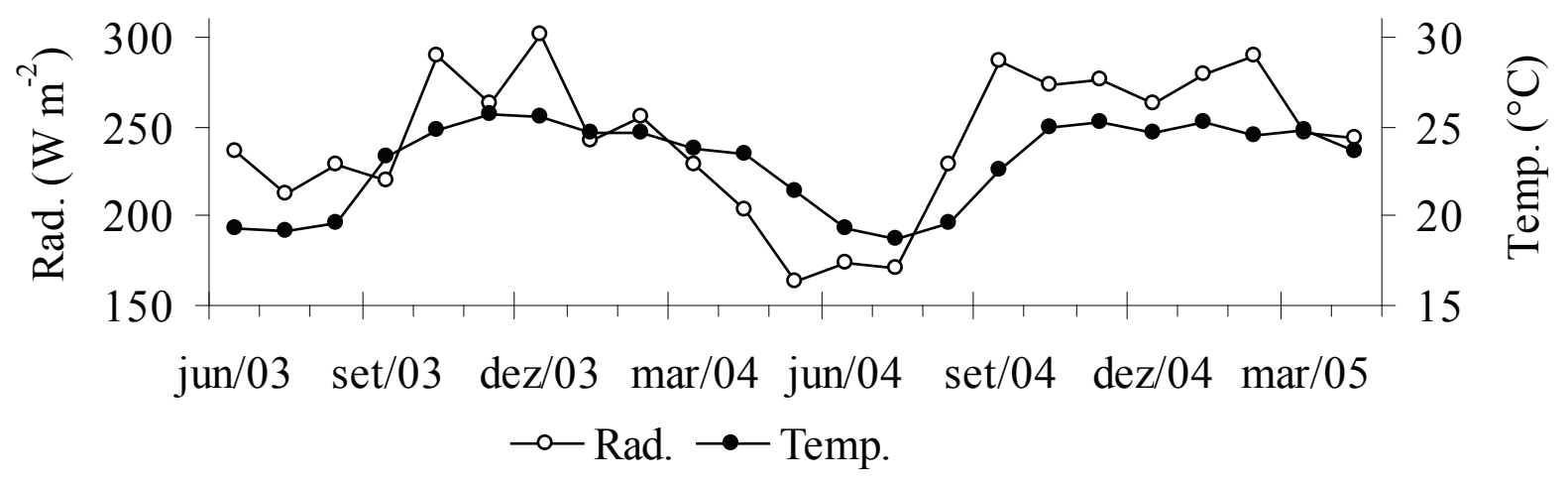

(A)

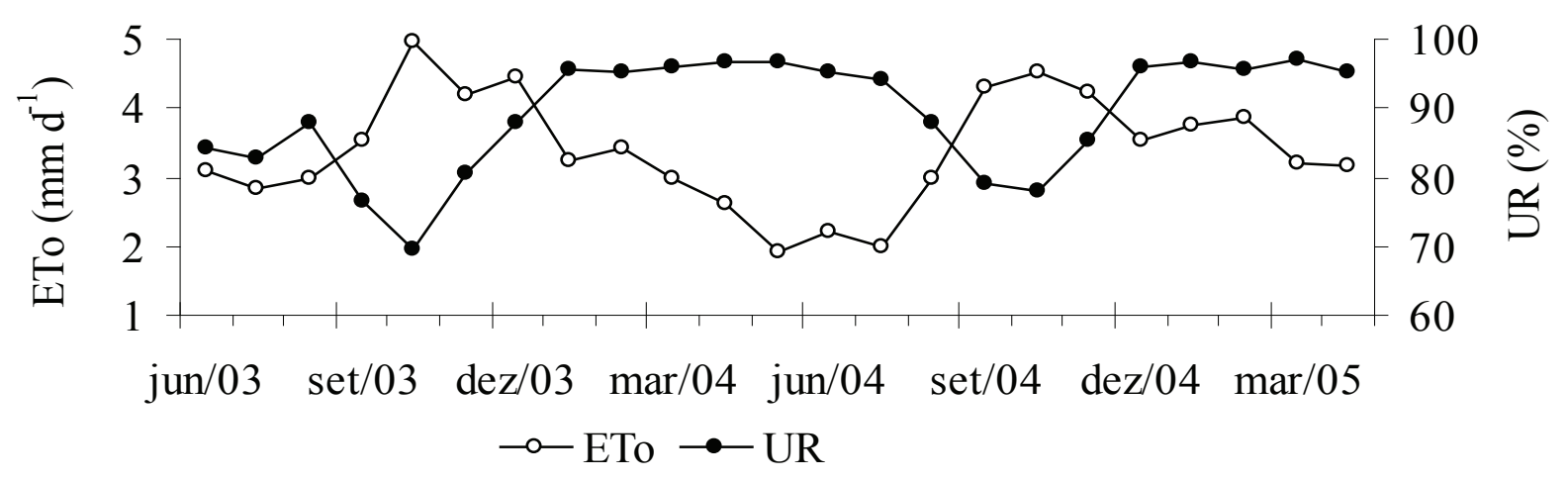

(B)

Figure 1. Variation of monthly climate data from June 2003 to April 2005: (A) solar radiation (Rad. in W $\mathrm{m}^{-2}$ ) and mean temperature (Temp. in ${ }^{\circ} \mathrm{C}$ ) and (B) reference evapotranspiration (ETo in $\mathrm{mm} \mathrm{d}^{-1}$ ) and relative humidity ( $\mathrm{RH}$ in \%).

There was significant interaction between the grasses and seasons (Table 1). Table 2 indicated that for the treatment with water depth of $45 \%$ of the reference $(252 \mathrm{~mm})$ and the spring-summer season, the grasses Pioneiro and Marandu showed the highest and lowest contents of crude protein (CP), respectively. Santos et al. (2003), evaluating several irrigated forages in the city of Recife, Brazil, also found that Pioneiro was the grass that showed the highest CP content. In the treatments with irrigation depths of $100 \%$ of the reference $(560 \mathrm{~mm})$ and during autumn/winter, it was observed that the Estrela grass presented the highest CP content $(p<0.05)$ and the grass species Brachiaria brizantha (Xaraés and Marandu) the lowest $(p<0.05)$ levels. For other treatments, no difference in the CP contents of the grasses was detected $(p<0.05)$. The protein levels found in this work are higher than others found in literature. Santos et al. (2003) reported CP levels contents of 10.2, 7.3, 7.2 and 7.0 for the grasses Pioneiro, Tanzania, Marandu and Mombaça, respectively. These figures presented by the authors were lower than those found in the present study, possibly due to management by cutting, a longer cutting interval (35 days) and less nitrogen fertilization $\left(50 \mathrm{~kg} \mathrm{ha}^{-1}\right.$ $\left.\mathrm{yr}^{-1}\right)$. França et al. (2007) observed that the CP content increased when cuttings were performed with greater frequency and higher nitrogen doses were applied. Cecato et al. (2001) evaluated the Estrela grass in Maringá, PR, Brazil and found CP contents ranging from 10.1 to $18.7 \%$.

It was also observed in Table 2 that CP levels were higher $(p<0.05)$ in the autumn/winter season only for treatments subjected to the irrigation depth of $77 \%$ of the reference $(431 \mathrm{~mm})$. For the other irrigation levels it was generally observed that the seasons do not affect $(p>0.05)$ the CP content of the grasses evaluated. Published data is different, where experiments conducted in the

\section{REVENG


Table 1. Analysis of variance of the crude protein (CP), neutral detergent fiber (NDF) and in vitro digestibility dry matter (IVDMD)

\begin{tabular}{|c|c|c|c|c|}
\hline \multirow{2}{*}{ Source of Variation } & \multirow{2}{*}{$\begin{array}{l}\text { Degrees of } \\
\text { Freedom }\end{array}$} & \multicolumn{3}{|c|}{ Mean Square } \\
\hline & & $\mathrm{CP}$ & NDF & IVDMD \\
\hline Grass & 5 & $6.29 \mathrm{E}+01^{*}$ & $1.96 \mathrm{E}+02^{*}$ & $5.65 \mathrm{E}+02^{* *}$ \\
\hline Residue (a) & 6 & $1.49 \mathrm{E}+01$ & $5.96 \mathrm{E}+00$ & $1.19 \mathrm{E}+01$ \\
\hline Irrigation & 5 & $1.44 \mathrm{E}+00^{\mathrm{NS}}$ & $4.34 \mathrm{E}+00^{\mathrm{NS}}$ & $1.99 \mathrm{E}+01^{\mathrm{NS}}$ \\
\hline Irrigation $\mathrm{x}$ Grass & 25 & $2.66 \mathrm{E}+00^{\mathrm{NS}}$ & $4.14 \mathrm{E}+00^{\mathrm{NS}}$ & $3.01 \mathrm{E}+01^{* *}$ \\
\hline Residue (b) & 30 & $2.55 \mathrm{E}+00$ & $4.94 \mathrm{E}+00$ & $8.75 \mathrm{E}+00$ \\
\hline Season & 1 & $4.85 \mathrm{E}+02^{* *}$ & $2.87 \mathrm{E}+02^{* *}$ & $2.82 \mathrm{E}+03^{* *}$ \\
\hline Season x Grass & 5 & $1.77 \mathrm{E}+01^{* *}$ & $3.25 \mathrm{E}+01^{* *}$ & $2.44 \mathrm{E}+02^{* *}$ \\
\hline Season $\mathrm{x}$ Irrigation & 5 & $3.66 \mathrm{E}+00^{\mathrm{NS}}$ & $6.87 \mathrm{E}+00^{\mathrm{NS}}$ & $3.03 \mathrm{E}+01^{\mathrm{NS}}$ \\
\hline Season $\mathrm{x}$ Grass $\mathrm{x}$ Irrigation & 25 & $1.29 \mathrm{E}+00^{\mathrm{NS}}$ & $2.28 \mathrm{E}+00^{\mathrm{NS}}$ & $1.58 \mathrm{E}+01^{\mathrm{NS}}$ \\
\hline Residue (c) & 36 & $3.42 \mathrm{E}+00$ & $6.89 \mathrm{E}+00$ & $1.70 \mathrm{E}+01$ \\
\hline Total & 143 & $7.08 \mathrm{E}+00$ & $1.15 \mathrm{E}+01$ & $5.78 \mathrm{E}+01$ \\
\hline CV (\%) Plot & & 33.37 & 3.51 & 6.77 \\
\hline CV (\%) Split Plot & & 13.81 & 3.20 & 5.82 \\
\hline CV (\%) Split Split Plot & & 15.98 & 3.77 & 8.11 \\
\hline
\end{tabular}

spring/summer season provide higher CP levels. Machado et al. (1998), when evaluating the grasses Mombaça and Tanzania, revealed higher protein levels in the rainy season (spring/summer) and lower levels in the dry season (autumn/winter). Gerdes et al. (2000) evaluated the grasses Marandu and Tanzania in the city of Nova Odessa, Brazil, in rainfed crops for cutting intervals of 35 days and nitrogen fertilization of $100 \mathrm{~kg} \mathrm{ha}^{-1} \mathrm{yr}^{-1}$, observing that CP levels were $17 \%$ and $12 \%$ in spring/summer and autumn/winter, respectively.

The irrigation depths of $0(0 \mathrm{~mm}), 45(252 \mathrm{~mm})$, $77(431 \mathrm{~mm})$ and $120 \%(672 \mathrm{~mm})$ of the reference value determined using the tensiometer and spring/summer season for the grasses presented no difference in the content of neutral detergent fiber (NDF) (Table 3). In the other treatments it was generally observed that the grasses Estrela and Pioneiro were those with the highest $(p<0.05)$ and lowest $(p<0.05)$ NDF contents, respectively. According to Corrêa et al. (2007), plants of the genus Cynodon, which includes the Estrela grass, are characterized by having a high proportion of
NDF; they also have relatively low lignin content which results in good quality.

The NDF contents found for the grasses Mombaça and Tanzania were below $75 \%$. Santos et al. (2003) when working with various irrigated forages in the city of Recife, Brazil, found the following results for NDF contents: Pioneiro (68.1\%), Marandu (74.8\%), Mombaça (77.5\%) and Tanzania (79.2\%).Effects of the season on NDF contents in the grasses was not observed $(p>0.05)$. This result was not expected since the rapid elongation of the grass leaf in the spring/summer season should result in greater participation of the constituent cell wall and consequently the NDF content as well. Machado et al. (1998) also observed the same behavior where the NDF contents in the rainy season were 73.4 and $75.1 \%$, while in the dry season were 69.6 and $70.1 \%$ for the grasses Mombaça and Tanzania, respectively. In general, Gerdes et al. (2000) found that the spring and summer seasons showed NDF contents around 17.7 and $15.9 \%$ higher than those of the autumn and winter seasons in Marandu and Tanzania 
Table 2. Average levels of crude protein (\%) for cultivated grasses under grazing and submitted to different irrigation levels at during different seasons

\begin{tabular}{|c|c|c|c|c|c|c|}
\hline \multirow{2}{*}{ Grass } & \multicolumn{2}{|c|}{$0 \%(0 \mathrm{~mm})$} & \multicolumn{2}{|c|}{$18 \%(101 \mathrm{~mm})$} & \multicolumn{2}{|c|}{$45 \%(252 \mathrm{~mm})$} \\
\hline & Aut./Win. & Spr./Sum. & Aut./Win. & Spr./Sum. & Aut./Win. & Spr./Sum. \\
\hline Xaraés & $12.01 \mathrm{Aa}$ & $9.17 \mathrm{Aa}$ & $10.64 \mathrm{Aa}$ & $8.14 \mathrm{Aa}$ & $10.02 \mathrm{ABa}$ & $8.32 \mathrm{Aa}$ \\
\hline Mombaça & $11.70 \mathrm{Aa}$ & $8.25 \mathrm{Aa}$ & $12.17 \mathrm{Aa}$ & $9.31 \mathrm{Aa}$ & $13.93 \mathrm{ABa}$ & $8.14 \mathrm{Ab}$ \\
\hline Tanzânia & $14.08 \mathrm{Aa}$ & $7.93 \mathrm{Ab}$ & $12.29 \mathrm{Aa}$ & $8.04 \mathrm{Aa}$ & $13.70 \mathrm{ABa}$ & $7.52 \mathrm{Ab}$ \\
\hline Pioneiro & $15.63 \mathrm{Aa}$ & $11.69 \mathrm{Aa}$ & $15.12 \mathrm{Aa}$ & $11.75 \mathrm{Aa}$ & $15.80 \mathrm{Aa}$ & $12.13 \mathrm{Aa}$ \\
\hline Marandu & $11.90 \mathrm{Aa}$ & $12.20 \mathrm{Aa}$ & $12.45 \mathrm{Aa}$ & $10.83 \mathrm{Aa}$ & $9.56 \mathrm{Ba}$ & $9.15 \mathrm{Aa}$ \\
\hline Estrela & $15.55 \mathrm{Aa}$ & $11.38 \mathrm{Ab}$ & $15.76 \mathrm{Aa}$ & $11.47 \mathrm{Aa}$ & $15.25 \mathrm{ABa}$ & $12.55 \mathrm{Aa}$ \\
\hline
\end{tabular}

\begin{tabular}{|c|c|c|c|c|c|c|}
\hline \multirow{2}{*}{ Grass } & \multicolumn{2}{|c|}{$77 \%(431 \mathrm{~mm})$} & \multicolumn{2}{|c|}{$100 \%(560 \mathrm{~mm})$} & \multicolumn{2}{|c|}{$120 \%(672 \mathrm{~mm})$} \\
\hline & Aut./Win. & Spr./Sum. & Aut./Win. & Spr./Sum. & Aut./Win. & Spr./Sum. \\
\hline Xaraés & $11.30 \mathrm{Aa}$ & $7.28 \mathrm{Ab}$ & $10.44 \mathrm{Ba}$ & $8.16 \mathrm{Aa}$ & $12.74 \mathrm{Aa}$ & $9.10 \mathrm{Aa}$ \\
\hline Mombaça & $15.86 \mathrm{Aa}$ & $8.39 \mathrm{Ab}$ & $13.14 \mathrm{ABa}$ & $8.67 \mathrm{Aa}$ & $13.67 \mathrm{Aa}$ & $8.87 \mathrm{Ab}$ \\
\hline Tanzânia & $12.75 \mathrm{Aa}$ & $7.42 \mathrm{Ab}$ & $14.89 \mathrm{ABa}$ & $8.94 \mathrm{Ab}$ & $14.54 \mathrm{Aa}$ & $7.81 \mathrm{Ab}$ \\
\hline Pioneiro & $16.62 \mathrm{Aa}$ & $11.49 \mathrm{Ab}$ & $15.31 \mathrm{ABa}$ & $12.07 \mathrm{Aa}$ & $15.82 \mathrm{Aa}$ & $12.78 \mathrm{Aa}$ \\
\hline Marandu & $11.49 \mathrm{Aa}$ & $7.80 \mathrm{Ab}$ & $10.15 \mathrm{Ba}$ & $11.37 \mathrm{Aa}$ & $10.77 \mathrm{Aa}$ & $10.14 \mathrm{Aa}$ \\
\hline Estrela & $15.22 \mathrm{Aa}$ & $9.37 \mathrm{Ab}$ & $17.23 \mathrm{Aa}$ & $11.70 \mathrm{Ab}$ & $13.00 \mathrm{Aa}$ & $11.07 \mathrm{Aa}$ \\
\hline
\end{tabular}

Means followed by different lower-case letters on the line for each water depth, and followed by different uppercase letters in the column indicate significant difference by the Tukey test $(p<0.05)$.

Table 3. Average levels of neutral detergent fiber (\%) for cultivated grasses under grazing and submitted to different irrigation levels at different seasons

\begin{tabular}{|c|c|c|c|c|c|c|}
\hline \multirow{2}{*}{ Grass } & \multicolumn{2}{|c|}{$0 \%(0 \mathrm{~mm})$} & \multicolumn{2}{|c|}{$18 \%(101 \mathrm{~mm})$} & \multicolumn{2}{|c|}{$45 \%(252 \mathrm{~mm})$} \\
\hline & Aut./Win. & Spr./Sum. & Aut./Win. & Spr./Sum. & Aut./Win. & Spr./Sum. \\
\hline Xaraés & $66.23 \mathrm{BCa}$ & $68.19 \mathrm{Aa}$ & $68.18 \mathrm{ABa}$ & $67.06 \mathrm{Ba}$ & $65.81 \mathrm{ABa}$ & $70.69 \mathrm{Aa}$ \\
\hline Mombaça & $71.12 \mathrm{ABa}$ & $72.25 \mathrm{Aa}$ & $69.19 \mathrm{ABa}$ & $70.61 \mathrm{ABa}$ & $69.41 \mathrm{ABa}$ & $69.74 \mathrm{Aa}$ \\
\hline Tanzânia & $66.96 \mathrm{BCa}$ & $71.37 \mathrm{Aa}$ & $68.62 \mathrm{ABa}$ & $72.33 \mathrm{ABa}$ & $69.97 \mathrm{ABa}$ & $73.06 \mathrm{Aa}$ \\
\hline Pioneiro & $61.60 \mathrm{Cb}$ & $71.29 \mathrm{Aa}$ & $62.78 \mathrm{Ba}$ & $70.31 \mathrm{ABa}$ & $62.86 \mathrm{Bb}$ & $68.69 \mathrm{Aa}$ \\
\hline Marandu & $66.92 \mathrm{BCa}$ & 69.19 Aa & $65.58 \mathrm{ABa}$ & $65.33 \mathrm{Ba}$ & $67.95 \mathrm{ABa}$ & $66.67 \mathrm{Aa}$ \\
\hline Estrela & $73.72 \mathrm{Aa}$ & $74.98 \mathrm{Aa}$ & $72.26 \mathrm{Aa}$ & $75.11 \mathrm{Aa}$ & $72.20 \mathrm{Aa}$ & $73.58 \mathrm{Aa}$ \\
\hline
\end{tabular}

\begin{tabular}{|c|c|c|c|c|c|c|}
\hline \multirow{2}{*}{ Grass } & \multicolumn{2}{|c|}{$77 \%(431 \mathrm{~mm})$} & \multicolumn{2}{|c|}{$100 \%(560 \mathrm{~mm})$} & \multicolumn{2}{|c|}{$120 \%(672 \mathrm{~mm})$} \\
\hline & Aut./Win. & Spr./Sum. & Aut./Win. & Spr./Sum. & Aut./Win. & Spr./Sum. \\
\hline Xaraés & $68.14 \mathrm{ABa}$ & $71.04 \mathrm{Aa}$ & $70.01 \mathrm{Aa}$ & $70.09 \mathrm{ABa}$ & $66.99 \mathrm{BCa}$ & $69.26 \mathrm{Aa}$ \\
\hline Mombaça & $69.56 \mathrm{Aa}$ & $70.90 \mathrm{Aa}$ & $70.52 \mathrm{Aa}$ & $71.63 \mathrm{ABa}$ & $71.12 \mathrm{ABa}$ & $70.95 \mathrm{Aa}$ \\
\hline Tanzânia & $69.83 \mathrm{Aa}$ & $74.79 \mathrm{Aa}$ & $67.69 \mathrm{ABa}$ & $71.22 \mathrm{ABa}$ & $70.84 \mathrm{ABa}$ & $73.90 \mathrm{Aa}$ \\
\hline Pioneiro & $61.22 \mathrm{Bb}$ & $70.82 \mathrm{Aa}$ & $62.28 \mathrm{Ba}$ & $67.36 \mathrm{Ba}$ & $63.15 \mathrm{Ca}$ & $68.04 \mathrm{Aa}$ \\
\hline Marandu & $64.64 \mathrm{ABa}$ & $69.63 \mathrm{Aa}$ & $68.83 \mathrm{ABa}$ & $68.51 \mathrm{ABa}$ & $67.34 \mathrm{BCa}$ & $69.41 \mathrm{Aa}$ \\
\hline Estrela & $71.80 \mathrm{Aa}$ & $76.35 \mathrm{Aa}$ & $71.90 \mathrm{Aa}$ & $74.71 \mathrm{Aa}$ & $75.23 \mathrm{Aa}$ & $75.05 \mathrm{Aa}$ \\
\hline
\end{tabular}

Means followed by different lower-case letters on the line for each water depth, and followed by different uppercase letters in the column indicate significant difference by the Tukey test $(p<0.05)$.

336 REVENG 331-340p. 
grasses, respectively.Table 4 indicated that Estrela grass generally presented lower $(p<0.05)$ in vitro digestibility of dry matter (DM). This result can be explained by the fact that the grass has a higher NDF content (Table 3). The IVDMD contents of the Panicum cultivars are less than those found by Machado et al. (1998), which were 64.6 and $63.4 \%$ in the rainy season and 64.8 and $66.9 \%$ in the dry seasons for Mombaça and Tanzania grasses, respectively. The IVDMD contents found in Estrela grass were also lower than those obtained by Cecato et al. (2001) (61.2\%) and Alvim et al. (2003) (50.7\%), who worked with a nitrogen dose of $400 \mathrm{~kg} \mathrm{ha}^{-1} \mathrm{yr}^{-1}$ in Coronel Pacheco, Brazil.

By studying the effect of the seasons, it was found that in the grasses Xaraés, Mombaça and Tanzania the autumn/winter season showed higher $(p<0.05)$ IVDMD than the spring/summer season. The other treatments were not influenced $(p>0.05)$ by the season of the year with regards to IVDMD levels. Although the statistical effect has not been verified, it is observed that numerically the autumn/winter season resulted in higher average IVDMD contents due to the occurrence of lower temperatures (Figure 1). High temperatures promoted rapid growth and leaf development, which increases the amount of cell wall components and as a consequence, the participation of this component in the total plant dry matter as well. According to Wilson (1983), these effects are negatively correlated with IVDMD. In general, Gerdes et al. (2000) found that the autumn and winter seasons showed IVDMD contents around 6.9 and $11.2 \%$ higher than in the spring and summer for the grasses Marandu and Tanzania, respectively. Machado et al. (1998) also found the same for Tanzania grass.It was generally observed that grasses of the genus Panicum did not differ with regards to bromatologic evaluations or IVDMD content. Similarly, the grasses Xaraés and Marandu which are of the species Brachiaria brizantha also did not differ.

Table 5 presents the equations for estimating the $\mathrm{CP}, \mathrm{NDF}$ and IVDMD of the grasses in function of irrigation depth and season. From Table 5A it is observed that only Mombaça grass in the autumn/ winter season was affected $(p<0.05)$ by irrigation depth. The response was quadratic $(p<0.05)$, in which the maximum value taken from the regression equation was for the irrigation depth of $73.9 \%$ of the reference. Cóser et al. (2008), in the city of Coronel

Table 4. Mean values of in vitro digestibility of dry matter (\%) for cultivated grasses under grazing and submitted to different irrigation levels at different seasons

\begin{tabular}{|c|c|c|c|c|c|c|}
\hline \multirow{2}{*}{ Grass } & \multicolumn{2}{|c|}{$0 \%(0 \mathrm{~mm})$} & \multicolumn{2}{|c|}{$18 \%(101 \mathrm{~mm})$} & \multicolumn{2}{|c|}{$45 \%(252 \mathrm{~mm})$} \\
\hline & Aut./Win. & Spr./Sum. & Aut./Win. & Spr./Sum. & Aut./Win. & Spr./Sum. \\
\hline Xaraés & $46.62 \mathrm{Ba}$ & $46.49 \mathrm{ABa}$ & $63.10 \mathrm{Aa}$ & $46.55 \mathrm{Ab}$ & $62.84 \mathrm{Aa}$ & $47.31 \mathrm{Ab}$ \\
\hline Mombaça & $53.86 \mathrm{ABa}$ & $40.67 \mathrm{ABb}$ & $64.02 \mathrm{Aa}$ & $42.44 \mathrm{Ab}$ & $59.94 \mathrm{Aa}$ & $44.54 \mathrm{Ab}$ \\
\hline Tanzânia & $64.00 \mathrm{Aa}$ & $50.14 \mathrm{ABb}$ & $59.85 \mathrm{ABa}$ & $48.04 \mathrm{Ab}$ & $60.27 \mathrm{Aa}$ & $49.66 \mathrm{Ab}$ \\
\hline Pioneiro & $51.90 \mathrm{ABa}$ & $55.38 \mathrm{Aa}$ & $51.77 \mathrm{ABa}$ & $51.83 \mathrm{Aa}$ & $51.95 \mathrm{ABa}$ & $49.50 \mathrm{Aa}$ \\
\hline Marandu & $48.06 \mathrm{Ba}$ & $49.99 \mathrm{ABa}$ & $50.20 \mathrm{ABa}$ & $52.33 \mathrm{Aa}$ & $50.80 \mathrm{ABa}$ & $49.74 \mathrm{Aa}$ \\
\hline Estrela & $46.64 \mathrm{Ba}$ & $37.38 \mathrm{Ba}$ & $47.07 \mathrm{Ba}$ & $40.61 \mathrm{Aa}$ & $45.08 \mathrm{Ba}$ & $38.87 \mathrm{Aa}$ \\
\hline \multirow{2}{*}{ Grass } & \multicolumn{2}{|c|}{$77 \%(431 \mathrm{~mm})$} & \multicolumn{2}{|c|}{$100 \%(560 \mathrm{~mm})$} & \multicolumn{2}{|c|}{$120 \%(672 \mathrm{~mm})$} \\
\hline & Aut./Win. & Spr./Sum. & Aut./Win. & Spr./Sum. & Aut./Win. & Spr./Sum. \\
\hline Xaraés & $64.50 \mathrm{Aa}$ & $51.42 \mathrm{Ab}$ & $62.44 \mathrm{Aa}$ & $49.84 \mathrm{Ab}$ & $65.40 \mathrm{Aa}$ & $51.13 \mathrm{Ab}$ \\
\hline Mombaça & $66.96 \mathrm{Aa}$ & $46.09 \mathrm{ABb}$ & $58.87 \mathrm{Aa}$ & $42.63 \mathrm{Ab}$ & $59.27 \mathrm{Aa}$ & $43.53 \mathrm{Ab}$ \\
\hline Tanzânia & $62.20 \mathrm{Aa}$ & $45.66 \mathrm{ABb}$ & $60.37 \mathrm{Aa}$ & $47.90 \mathrm{Ab}$ & $61.88 \mathrm{Aa}$ & $44.70 \mathrm{Ab}$ \\
\hline Pioneiro & $52.95 \mathrm{ABa}$ & $48.30 \mathrm{Aa}$ & $49.90 \mathrm{ABa}$ & $48.65 \mathrm{Aa}$ & $53.72 \mathrm{Aa}$ & $46.76 \mathrm{Aa}$ \\
\hline Marandu & $53.67 \mathrm{ABa}$ & $48.35 \mathrm{Aa}$ & $50.73 \mathrm{ABa}$ & $50.76 \mathrm{Aa}$ & $60.70 \mathrm{Aa}$ & $50.25 \mathrm{Ab}$ \\
\hline Estrela & $46.67 \mathrm{Ba}$ & $36.52 \mathrm{Ba}$ & $46.03 \mathrm{Ba}$ & $39.87 \mathrm{Aa}$ & $35.81 \mathrm{Ba}$ & $37.67 \mathrm{Aa}$ \\
\hline
\end{tabular}

Means followed by different lower-case letters on the line for each water depth, and followed by different uppercase letters in the column indicate significant difference by the Tukey test $(p<0.05)$. 
Table 5. Regression equations and determination coefficients $\left(\mathrm{R}^{2}\right)$ of $(\mathrm{A})$ crude protein (\%), (B) neutral detergent fiber (\%) and (C) in vitro dry matter digestibility (\%) for six grasses in function of irrigation ( $\mathrm{L}$, in \% of the reference) and the seasons autumn/winter and spring/summer

A.

\begin{tabular}{|c|c|c|c|}
\hline Grass & Season & Equation & $\mathrm{R}^{2}$ \\
\hline \multirow{2}{*}{ Xaraés } & Autumn/Winter & $\mathrm{CP}=11.1908$ & - \\
\hline & Spring/Summer & $\mathrm{CP}=8.3608$ & - \\
\hline \multirow{2}{*}{ Mombaça } & Autumn/Winter & $\mathrm{CP}=11.3151+0.0904 * \mathrm{~L}-0.0006^{*} \mathrm{~L}^{2}$ & 0.70 \\
\hline & Spring/Summer & $\mathrm{CP}=8.6025$ & - \\
\hline \multirow{2}{*}{ Tanzânia } & Autumn/Winter & $\mathrm{CP}=13.7050$ & - \\
\hline & Spring/Summer & $\mathrm{CP}=7.9400$ & - \\
\hline \multirow{2}{*}{ Pioneiro } & Autumn/Winter & $\mathrm{CP}=15.7133$ & - \\
\hline & Spring/Summer & $\mathrm{CP}=11.9833$ & - \\
\hline \multirow{2}{*}{ Marandu } & Autumn/Winter & $\mathrm{CP}=11.0517$ & - \\
\hline & Spring/Summer & $\mathrm{CP}=10.2458$ & - \\
\hline \multirow{2}{*}{ Estrela } & Autumn/Winter & $\mathrm{CP}=15.3333$ & - \\
\hline & Spring/Summer & $\mathrm{CP}=11.2542$ & - \\
\hline
\end{tabular}

B.

Grass

Season

Equation

$\mathrm{R}^{2}$

\begin{tabular}{lllc}
\hline \multirow{2}{*}{ Xaraés } & Autumn/Winter & $\mathrm{NDF}=67.5583$ & - \\
& Spring/Summer & $\mathrm{NDF}=67.2740+0.0903 * \mathrm{~L}-0.0006 * \mathrm{~L}^{2}$ & - \\
\hline \multirow{2}{*}{ Mombaça } & Autumn/Winter & $\mathrm{NDF}=70.1500$ & - \\
& Spring/Summer & $\mathrm{NDF}=71.0092$ & - \\
\hline \multirow{2}{*}{ Tanzânia } & Autumn/Winter & $\mathrm{NDF}=68.9833$ & - \\
& Spring/Summer & $\mathrm{NDF}=72.7733$ & - \\
\hline \multirow{2}{*}{ Pioneiro } & Autumn/Winter & $\mathrm{NDF}=62.3150$ & 0.55 \\
& Spring/Summer & $\mathrm{NDF}=70.9305-0.0253 * \mathrm{~L}$ & - \\
\multirow{2}{*}{ Marandu } & Autumn/Winter & $\mathrm{NDF}=66.8750$ & - \\
\hline \multirow{2}{*}{ Estrela } & Spring/Summer & $\mathrm{NDF}=68.1225$ & - \\
& Autumn/Winter & $\mathrm{NDF}=72.8517$ & - \\
\hline
\end{tabular}

C.

\begin{tabular}{|c|c|c|c|}
\hline Grass & Season & Equation & $\mathrm{R}^{2}$ \\
\hline \multirow{2}{*}{ Xaraés } & Autumn/Winter & IVDMD $=50.8245+0.3728 * * \mathrm{~L}-0.0023 * \mathrm{~L}^{2}$ & 0.70 \\
\hline & Spring/Summer & $\operatorname{IVDMD}=46.1806+0.0434 * * \mathrm{~L}$ & 0.81 \\
\hline \multirow{2}{*}{ Mombaça } & Autumn/Winter & IVDMD $=55.8034+0.2607 * \mathrm{~L}-0.0020 * \mathrm{~L}^{2}$ & 0.49 \\
\hline & Spring/Summer & IVDMD $=40.6336+0.1266 * * \mathrm{~L}-0.0009 * \mathrm{~L}^{2}$ & 0.75 \\
\hline \multirow{2}{*}{ Tanzânia } & Autumn/Winter & IVDMD $=61.4250$ & - \\
\hline & Spring/Summer & IVDMD $=49.8298-0.0358 * \mathrm{~L}$ & 0.62 \\
\hline \multirow{2}{*}{ Pioneiro } & Autumn/Winter & IVDMD $=52.0292$ & - \\
\hline & Spring/Summer & IVDMD $=53.6955-0.0604 * * \mathrm{~L}$ & 0.85 \\
\hline \multirow{2}{*}{ Marandu } & Autumn/Winter & $\mathrm{IVDMD}=47.8656+0.0749 * \mathrm{~L}$ & 0.63 \\
\hline & Spring/Summer & IVDMD $=50.2333$ & - \\
\hline \multirow{2}{*}{ Estrela } & Autumn/Winter & IVDMD $=45.6049+0.1186^{*} \mathrm{~L}-0.0015^{*} \mathrm{~L}^{2}$ & 0.70 \\
\hline & Spring/Summer & IVDMD $=38.4833$ & - \\
\hline
\end{tabular}

** and * significant at 1 and $5 \%$ probability, respectively.

\section{REVENG}


Pacheco, Brazil did not verify the effect of irrigation on the CP content of elephant grass. Cunha et al. (2007) found different results when evaluating Tanzania grass the city of Viçosa, Brazil. These authors found lower levels of CP in treatments with higher irrigation. The explanation of a nonincreasing effect resulting from water depth on the $\mathrm{CP}$ content may be based on the methodology for its determination. In this case only the potentially consumable material was harvested, manly the leaf. If the stem was included together with the leaf then there may have been a greater effect.

From Table 5B it was observed that during the spring/summer season the NDF content of the grass Pioneiro presented a linear negative response $(p<0.05)$ to water depth; in other words, the increase in water depth resulted in a reduced NDF content. The Xaraés grass responded quadratically $(p<0.05)$, where the maximum value was taken from the regression equation at the irrigation depth of $74.4 \%$ of the reference. In other treatments there was no response $(p>0.05)$. Barreto et al. (2001) working with elephant grass and Cunha et al. (2007) with Tanzania grass also found no response of NDF content to increased water depth. Despite the lack of response some authors reported that plants under water stress have lower cell wall levels (WILSON, 1983).

The effect resulting from increasing the irrigation depths on the IVDMD was dependent on the grass and the season (Table 5C). It was observed in autumn/ winter that the depth irrigation had a positive linear effect $(p<0.05)$ on Marandu grass and quadratic effect $(p<0.05)$ on the grasses Xaraés, Mombaça and Estrela, whose maximum values obtained from the regression equations were for irrigation depths of 82,64 and $40 \%$ of the reference, respectively. The other grasses were not affected $(p>0.05)$. In the spring/summer season, irrigation had a positive linear effect $(p<0.05)$ on Xaraés grass, linear negative effect $(p<0.05)$ on Tanzania and Pioneiro grasses and a quadratic effect $(p<0.05)$ on Mombaça grass, whose maximum value obtained from the regression equation was for the irrigation depth of $70 \%$ of the reference. In the studies of Barreto et al. (2001), Cóser et al. (2008) and Victor et al. (2009) evaluating Elephant grass and Cunha et al. (2007) evaluating Tanzania grass, no difference in the IVDMD value was found in response to irrigation.

\section{CONCLUSIONS}

- The grasses and seasons had an effect on the crude protein content;

- In the spring/summer season the grasses did not affect the content of neutral detergent fiber and in autumn/winter the grasses Estrela and Pioneiro had the highest and lowest levels, respectively;

- The seasons and irrigation depth did not affect the content of neutral detergent fiber;

- Estrela grass presented the lowest in vitro digestibility of dry matter;

- The autumn/winter season only resulted in greater digestibility for the grasses Xaraés, Mombaça and Tanzania;

- The irrigation depths had an effect on some combinations of grasses and season.

\section{REFERENCES}

ALENCAR, C.A.B.; MARTINS, C.E.; CÓSER, A.C.; OLIVEIRA, R.A.; CUNHA, F.F. Bromatologia e digestibilidade de gramíneas manejadas por corte submetidas a diferentes lâminas de irrigação. Engenharia na Agricultura, v.18, n.6, p.504-513, 2010.

ALVIM, M.J.; BOTREL, M.A.; REZENDE, H.; XAVIER, D.F. Avaliação sob pastejo do potencial forrageiro de gramíneas do gênero Cynodon, sob dois níveis de nitrogênio e potássio. Revista Brasileira de Zootecnia, v.32, n.1, p.47-54, 2003.

AROEIRA, L.J.M.; LOPES, F.C.F.; DERESZ, F.; VERNEQUE, R.S.; DAYRELL, M.S.; MATOS, L.L.; MALDONADO VASQUEZ, H.; VITTORI, A. Pasture availability and dry matter intake of lactating crossbred cows grazing elephant grass (Pennisetum purpureum, Schum). Animal Feed Science and Technology, v.78, n.3, p.313-324, 1999.

BARRETO, G.P.; LIRA, M.A.; SANTOS, M.V.F.; DUBEUX Jr., J.C.B. Avaliação de clones de capim-elefante (Pennisetum purpureum Schum.) e de um híbrido com o milheto (Pennisetum glaucum (L.) R. Br.) submetidos a estresse hídrico. 2. Valor 
nutritivo. Revista Brasileira de Zootecnia, v.30, n.1, p.7-11, 2001.

CECATO, U.; CANO, C.C.P.; BORTOLO, M.; HERLING, V.R.; CANTO, M.W.; CASTRO, C.R.C. Teores de carboidratos não-estruturais, nitrogênio total e peso de raízes em Coastacross-1 (Cynodon dactylon (L.) Pers) pastejado por ovinos. Revista Brasileira de Zootecnia, v. 30, n.3, p.644-650, 2001.

CORRÊA, L.A.; CANTARELLA, H.; PRIMAVESI, A.C.; PRIMAVESI, O.; FREITAS, A.R.; SILVA, A.G. Efeito de fontes e doses de nitrogênio na produção e qualidade da forragem de capim-coastcross. Revista Brasileira de Zootecnia, v.36, n.4, p.763-772, 2007.

CÓSER, A.C.; MARTINS, C.E.; DERESZ, F.; FREITAS, A.F.; PACIULLO, D.S.C.; ALENCAR, C.A.B.; VITOR, C.M.T. Produção de forragem e valor nutritivo do capim-elefante, irrigado durante a época seca. Pesquisa Agropecuária Brasileira, v.43, n.11, p.1625-1631, 2008.

CUNHA, F.F.; SOARES, A.A.; PEREIRA, O.G.; MANTOVANI, E.C.; SEDIYAMA, G.C.; ABREU, F.V.S. Composição bromatológica e digestibilidade in vitro da matéria seca do capim-tanzânia irrigado. Bioscience Journal, v.23, n.2, p.25-33, 2007.

FRANÇA, A.F.S.; BORJAS, A.L.R.; OLIVEIRA, E.R.; SOARES, T.V.; MIYAGI, E.S.; SOUZA, V.R. Parâmetros nutricionais do capim-tanzânia sob doses crescentes de nitrogênio em diferentes idades de corte. Ciência Animal Brasileira, v.8, n.4; p.695-703, 2007.

GERDES, L.; WERNER, J.C.; COLOZZA, M.T.; POSSENTI, R.A.; SCHAMMASS, E.A. Avaliação de características de valor nutritivo das gramíneas forrageiras Marandu, Setária e Tanzânia nas estações do ano. Revista Brasileira de Zootecnia, v.29, n.4, p.955-963, 2000.

HANKS, R.J.; KELLER, J.; RASMUSSEN, V.P.; WILSON, G.D. Line source sprinkler for continuous variable irrigation crop production studies. Soil Science of American Journal, v.40, n.3, p.426-429, 1976.

LIMA, M.L.P.; BERCHIELLI, T.T.; NOGUEIRA, J.R.; RUGGIERI, A.C.; AROEIRA, L.J.M.;
SALMAN, A.K.D.; SOARES, J.P.G. Estimativa do consumo voluntário do capim-tanzânia (Panicum maximum, Jacq. cv. Tanzânia) por vacas em lactação sob pastejo rotacionado. Revista Brasileira de Zootecnia, v.30, n.6, p.1919-1924, 2001.

MACHADO, A.O.; CECATO, U.; MIRA, R.T.; PEREIRA, L.A.F.; DAMASCENO, J.C. Avaliação da composição química e digestibilidade in vitro da matéria seca de cultivares e acessos de Panicum maximum Jacq. sob duas alturas de corte. Revista Brasileira de Zootecnia, v.27, n.5, p.1057-1063, 1998.

MARCELINO, K.R.A.; VILELA, L.; LEITE, G.G.; GUERRA, A.F.; DIOGO, J.M.S. Manejo da adubação nitrogenada e de tensões hídricas sobre a produção de matéria seca e índice de área foliar de Tifton 85 cultivado no Cerrado. Revista Brasileira de Zootecnia, v.32, n.2, p.268-275, 2003.

REIS, R.A.; RODRIGUES, L.R.A.; COAN, O. Efeitos de epocas de colheita sobre a producao de forragem e de sememtes de aveia preta. Pesquisa Agropecuária Brasileira, v.27, n.1, p.111-117, 1992.

RICHARDS, L.A. Methods of measuring soil moisture tension. Soil Science of American Journal, v.68, n.1, p.95-112, 1949.

SANTOS, M.V.F.; DUBEUX Jr., J.C.B.; SILVA, M.C.; SANTOS, S.F.; FERREIRA, R.L.C.; MELLO, A.C.L.; FARIAS, I.; FREITAS, E.V. Produtividade e composição química de gramíneas tropicais na zona da mata de Pernambuco. Revista Brasileira de Zootecnia, v.32, n.4, p.821-827, 2003.

SILVA, D.J.; QUEIROZ, A.C. Análises de alimentos (métodos químicos e biológicos). 3.ed. Viçosa: Imprensa Universitária, 2002. 235p.

VÍTOR, C.M.T.; FONSECA, D.M.; CÓSER, A.C.; MARTINS, C.E.; NASCIMENTO Jr., D.; RIBEIRO Jr., J.I. Produção de matéria seca e valor nutritivo de pastagem de capim-elefante sob irrigação e adubação nitrogenada. Revista Brasileira de Zootecnia, v.38, n.3, p.435-442, 2009.

WILSON, J.R. Effects of water stress on in vitro dry matter digestibility and chemical composition of herbage of tropical pasture species. Australian Journal of Agricultural Research, v.34, n.4, p.377-390, 1983.

\section{REVENG}

